\title{
Governance and Poverty Reduction in Thailand
}

\author{
Pornpen Vora-Sittha \\ Graduate School of Development Economics, National Institute of Development Administration, \\ Bangkok, Thailand \\ Email: pornpen_econ@yahoo.com
}

Received May 9, 2012; revised June 8, 2012; accepted June 16, 2012

\begin{abstract}
The objective of this study is to find out how Thailand achieves her economic growth along with poverty reduction without good governance practice. The relationships among economic growth, poverty indicators and governance indicators are computed by using Pearson's correlation. The computed results show that the poverty reduction in Thailand is achieved through populist policies which are exercised with low quality of governance, not through growth. It supports general belief that the "pro-poor growth" policy alone without good governance performance is insufficient for enhancing poverty reduction equally. A strategy for reducing poverty and income inequality for Thailand is not to enhance economic growth but to promote major improvements in governance especially in variable that reflect the perception in three governance composite indicators namely Voice and Accountability, Political Stability and Absence of Violence, and Rule of Law.
\end{abstract}

Keywords: Governance; Growth; Poverty; Income Inequality; Governance and Poverty Reduction; Thailand

\section{Introduction}

In Neoclassical theory, faster economic growth is associated with faster poverty reduction if the benefits from growth are also distributed to the poor. The general known facts in several countries, however, do not support such linkage. This generates a debate on the issue of the actual contribution of economic growth to poverty reduction efforts to be effective. Good governance has been introduced in this scene as a necessary condition for poverty reduction attempts to be exercised in such a way that benefits from growth will also fairly distributed to the poor. If the government power is abused, or is exercised in weak or improper ways, the poor are those most likely to suffer. Moreover, poor governance also generates and reinforces poverty, and makes poverty reduction efforts ineffective [1].

Over the past decade since 1998 to date, countries in all regions have shown substantial improvements in governance. Thailand is one among them and started having her public reform in governance since 1999. However, it is found that the quality of governance; the economic growth and the poverty reduction for Thailand do not coincide with the theory. The normative measures in the quality of governance for Thailand have declined since 2001, whereas the country experienced her rapid economic growth and decline in poverty incidence. How Thailand achieves her economic growth along with poverty reduction without good governance practice is a research question of this study.

The objective of this study is to assess relationship among the governance indicators, the economic growth and the poverty indicators which include income inequality in Thailand. The results are expected to support general belief that either growth or "pro-poor growth" policy alone is insufficient for enhancing poverty reduction equally. Good governance in exercising administrative power is a crucial factor not only in eradicating poverty but also reinforcing the process of being more equitable in income distribution.

The paper proceeds as follows. Section 2 provides scope, methodology and analytical framework for this study. Section 3 is an overview of Thailand's economic and political situation and a review of governance development in Thailand as a background for discussion of the relationship between good governance and poverty reduction. Section 4 presents results of the study and the last section is conclusion and policy implications.

\section{Scope, Methodology and Analytical Framework}

\subsection{Scope and Methodology}

The relationship between the poverty and the governance indicators is computed by means of Pearson's correlation. For the poverty measurement, even though there are various indicators that show the incidence of income poverty, two poverty indicators during 1996-2009 namely, 
poverty level (proportion of population below the poverty line (expenditure-based) ${ }^{1}$ and Gini inequality index ${ }^{2}$ are selected as indication for the poverty incidence in this study. In this study, the GDP per capita growth is used to represent growth rates for the Thai economy ${ }^{3}$.

Period under studied is in between 1996-2009. The 1996-1999 stands for the period before public reform in governance and the years after 2000 are in the period after the reform.

The Worldwide Governance Indicators (WGI) of World Bank during the period of 1996 to 2009 is used in this paper as the measures of the governance quality. The indicators include six composite indicators: Voice and Accountability, Political Stability and Violence, Government Effectiveness, Rule of Law, Regulatory Quality, and Control of Corruption. The point estimate of scores indicating perception on the governance quality are measured in units ranging from about -2.5 to 2.5 , with higher values corresponding to better governance outcomes. For the overall picture of governance quality for a country, scores summation of the six composite indicators in the corresponding period is used to represent the aggregate WGI.

\subsection{Defining Governance for This Study}

In 1993, the World Bank defined governance as the method through which power is exercised in the management of a country's political, economic and social resources for development. The use of the terms governance has been popular in both of their quest and usage in the nineteenth and twentieth century, as it helps enlarge and better illustrate what government should be focusing on. In development literature, the terms "good governance" is addressed as a crucial link in the road to development and poverty reduction; meanwhile, bad governance is being increasingly regarded as one of the root causes of all poverty within our societies [2].

In response to the growing demand on measures of the quality of governance, a number of aggregate governance indicators have been produced; such as the World Bank in 1992, UNDP in 1997 and Daniel Kaufmann et al. in 1999, etc. Data used to quantify governance normally come from expert assessments, polls of experts, and surveys of government officials, businesses and households. However, the surveys and polls from various sources do not share a common methodology, definition of terms, a

\footnotetext{
${ }^{1}$ Data that represent the proportion of population below the poverty line is an estimate of the percentage of the population falling below the poverty line. The data are officially developed by the National Economic and Social Development Board (NESDB) of Thailand, and is now used as the standard poverty line in most poverty analyses in the country.

${ }^{2}$ Gini-coefficient of inequality is the most commonly used in measuring inequality of income. The coefficient varies between 0 , which reflects complete equality and 1 , which indicates complete inequality (one person has all the income or consumption, all others have none).
}

set of questions or measurement scale of responses. This study will use the Worldwide Governance Indicators (WGI) which proposed by the World Bank as the indicators in measuring good governance, since it is one of the most reliable indicators to date.

The WGI rank countries on six composite indicators of "good governance", covered behavior of three parties in the society: public sector, private sector and civil society. The three of them are supposed to cooperate in managing socio-economic resources for national development. The indicators include three areas of traditions and institutions by which authority in a country is exercised: 1 ) the process by which governments are selected, monitored and replaced; 2) the capacity of the government to effecttively formulate and implement sound policies; and 3) the respect of citizens and the state for the institutions that govern economic and social interactions among them. Two measures of governance are constructed to quantify perception in each of these three areas, resulting in a total of six composite indicators of governance as follow [3].

1) The process by which governments are selected, monitored, and replaced:

Voice and Accountability (VA) — capturing perceptions of the extent to which a country's citizens are able to participate in selecting their government, as well as freedom of expression, freedom of association, and a free media.

Political Stability and Absence of Violence/Terrorism (PV) - capturing perceptions of the likelihood that the government will be destabilized or overthrown by unconstitutional or violent means, including politicallymotivated violence and terrorism.

2) The capacity of the government to effectively formulate and implement sound policies:

Government Effectiveness (GE) — capturing perceptions of the quality of public services, the quality of the civil service and the degree of its independence from political pressures, the quality of policy formulation and implementation, and the credibility of the government's commitment to such policies.

Regulatory Quality $(R Q)$ — capturing perceptions of the ability of the government to formulate and implement sound policies and regulations that permit and promote private sector development.

\footnotetext{
${ }^{3}$ Other poverty measures: per capita GDP, poverty gap ratio, share of poorest quintile in individual household expenditure, and proportion below food poverty line; are not used to analyze the linkage between the indicators of governance and poverty, because the Pearson's correlation coefficients as shown in Appendix 1 indicates that they are highly correlated with one another. Similarly, this study, the GDP per capita growth is used to represent growth rates for the Thai economy, since the GDP growth at constant 1988 price and the GDP per capita growth are also highly correlated with Pearson's coefficient of 0.989 (Appendix 1).
} 
3) The respect of citizens and the state for the institutions that govern economic and social interactions among them:

Rule of Law (RL) - capturing perceptions of the extent to which agents have confidence in and abide by the rules of society, and in particular the quality of contract enforcement, property rights, the police, and the courts, as well as the likelihood of crime and violence.

Control of Corruption (CC) - capturing perceptions of the extent to which public power is exercised for private gain, including both petty and grand forms of corruption, as well as "capture" of the state by elites and private interests.

\subsection{Analytical Framework}

The relationships among growth, poverty, income inequality, and governance are shown in Figure 1. Several economists believe that the type of growth that has a beneficial effect on both poverty reduction and improved in income distribution is "pro-poor" growth. It is postulated in this study that the "pro-poor growth" policy alone is insufficient for enhancing poverty reduction equally. Good governance is essential for pro-poor growth policy to be effective and to reinforce the process of income distribution.

\section{Country Background}

Most prominent agencies in the international development community now acknowledge that poverty reduction is as much a political as an economic issue. Therefore, this part will provide an overview of Thailand's economic and political situations and a review of governance development in Thailand as a background for discussion of the relationship between good governance and poverty reduction.

\subsection{Economic Background}

Thailand is currently an emerging economy in Southeast Asia and is considered as a newly industrialized country. The country is classified as the second largest economy in Southeast Asia after Indonesia. In addition, Thailand is ranked midway in terms of wealth spread in the region, since it is the fourth richest nation, based on GDP per capita, after Singapore, Brunei and Malaysia. In 2011, the World Bank has upgraded Thailand's income categorization from a lower-middle income to an upper-middle income economy with the Gross National Income (GNI) per capita at US $\$ 4.210$ comparing to the upper-middleincome economies which have average incomes of US $\$ 3.976$ to US $\$ 12.275$.

In the last several decades that ended in 1996, Thailand had been one of the great development success countries, with sustained strong growth at an average rate of

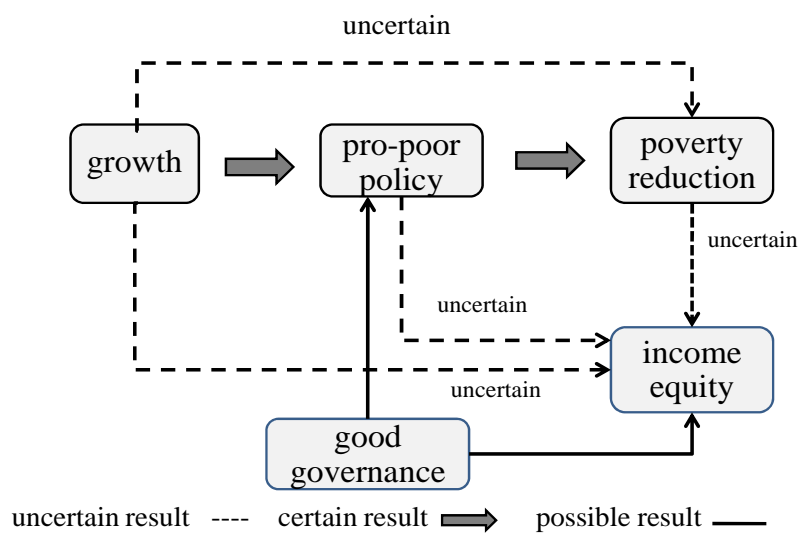

Figure 1. The relationship among growth, poverty, income inequality, and governance.

8\% - 9\% per year and with an impressive poverty reduction. Physical capital such as equipment and factories, both domestic and foreign, was the main contributor to this high growth rate. In no year from 1958 to 1996 did Thailand experience a year of negative growth of real output per head. Following the financial crisis that hit Thailand in 1997, however, Thailand's growth rate fell to -10.5 percent in 1998, the lowest it had been since before the 1996. Even though the crisis of 1997-1998 wiped off some gains that had been achieved in previous decades, the level of real GDP per person in 1998 was still seven times of its level in 1951.

About the poverty incidence, before the Asian financial crisis, Thailand has made an enormous progress in reducing the incidence of poverty with poverty level falling from 33 percent in 1990 to 14.75 percent in 1996. The economic crisis has changed the situation, pushing one million people into poverty. As is pointed out by Medhi Krongkaew, et al. [4] that it is the poor who suffered more than the others - during the boom period, the poor, especially those in the agricultural sector did not benefit as much as the rich, whereas during the crisis, the poor were among the worst hit millions lost their jobs.

After the crisis in 1997, Thailand's economic policies, as proposed in the National Economic and Development Plan, have focused more on improving rural standards of living and reducing rural poverty than trying to expand the economy in urban areas. The government's efforts does yield improvements in the reduction of poverty on the average as shown by GDP per capita growth, but the proportions of the poor who benefit from growth have been declining from 14.93 percent in 2002 to 8.10 in 2009 (Table 1).

Most economists attribute the continual and rapid decreases in poverty incidence to macroeconomic performance, and the government's selective policies adopted after the crisis. However, the performance cannot be claimed as national success since Gini coefficient, an index which 
measures the income inequality is rather stable and is declining slowly during the period of study from 42.90 in 1996 to 40.00 in 2009 (Table 1).

\subsection{Political Background}

The politics of Thailand are conducted within the framework of a constitutional monarchy after the "democratic revolution" in 1932, whereby the Prim Minister is the head of government and the King is the head of state. The judiciary is independent of the executive and the legislative branches. To date Thailand has had seventeen charters and constitutions, reflecting a high degree of political instability.

From 1932, bureaucrats, generals, and businessmen have run most of the political parties. No "grassroots" party has ever led the country. Money seems to be the major factor of gaining power in the country. Political power means control over the national resource. The Black May which uprising in 1992 lead to reform and promulgate the 1997 constitution which aimed to create checks and balance of powers between strengthened government, separately elected senators and anti-corruption institutes. Administrative courts, Constitutional Courts and electioncontrol committee were established to strengthen the checks and balance of politics. Disappointment in the 1997 constitution leads to the 2007 constitution, following Thaksin's ouster. The new constitution was particularly designed to be tighter in its control of corruptions and conflicts of interests while reducing the authority of the government but is still unsatisfied to date.

Political conflict arises in Thailand when Thaksin Shinawatra, the Prime Minister of Thailand in 2001, started implementing a range of populist economic policies and cracking down on groups critical of his government, including several media outlets and organizations that are part of Thailand's vibrant civil society. A battle in form of a conflict which leads to political turmoil broke out between the populists and conservatives since 2008. Coups happened from time to time, reflecting a high degree of political instability. A current temporary political stability happens in Thailand when successful coups, military regimes have abrogated existing constitutions and promulgated interim charters. Negotiation among politicians, men of influence and generals has become the prime factor for restoration of temporary political stability [5].

\subsection{How Is the Governance Matter for Thailand?}

After enjoying the world's highest average growth rate of 12.4 percent annually from 1985 to 1996, Thailand had faced the economic and the financial crisis in 1997-1998. Debate over the causes of the crisis was, in part, focused
Table 1. GDP growth, poverty measures and Gini coefficient for Thailand.

\begin{tabular}{cccccc}
\hline Year & $\begin{array}{c}\text { Poverty }^{*} \\
\text { Level }^{*}\end{array}$ & $\begin{array}{c}\text { Per } \\
\text { Capita GDP } \\
\text { (baht) }^{* * *}\end{array}$ & $\begin{array}{c}\text { GDP Per } \\
\text { Capita } \\
\text { Growth (\%) }\end{array}$ & $\begin{array}{c}\text { GDP } \\
\text { Growth } \\
(\%)^{* *}\end{array}$ & $\begin{array}{c}\text { Gini } \\
\text { Coefficient }^{*}\end{array}$ \\
\hline 1996 & 14.75 & 51,920 & 4.84 & 5.8 & 42.9 \\
1998 & 17.46 & 44,929 & -11.39 & -10.5 & 41.5 \\
2000 & 20.98 & 48,339 & 4.03 & 4.8 & 42.8 \\
2002 & 14.93 & 51,042 & 4.35 & 5.3 & 42 \\
2004 & 11.16 & 57,154 & 5.44 & 6.3 & 42.5 \\
2006 & 9.55 & 61,862 & 4.38 & 5.1 & 42.4 \\
2008 & 8.95 & 65,603 & 1.78 & 2.5 & 40.5 \\
2009 & 8.1 & 65,237 & -0.56 & -2.3 & 40 \\
\hline
\end{tabular}

Source: the National and Economic Development Board (NESDB), Thailand; *Represents the proportion of population below the poverty line (expenditure-based) (\%), ${ }^{* *}$ The GDP is at Constant 1988 Price.

on the critical weaknesses of the nations' economic governance. It is widely believed that the rapidly changing environment and the globalization trends had resulted in the unbalanced and non-sustainable development of some developing countries. But there are only some countries in Asia like Thailand, South Korea, Indonesia, etc. which encountered with severe structural damage, while some countries as Australia, for example, proved to be more resilient and adaptable than others to the Asian Crisis. The Asian Development Bank reported in 1999 that the crisis in Southeast Asian countries, including South Korea, was caused by a failure in implementing corporate governance and the good exercise of power in governance had been introduced to explain the above phenomenon [6].

For Thailand, it is apparent that prior to the crisis, inappropriate state management was incurred in different parts of Thai society. The Thai society has confronted a crisis of declining ethical and moral values and greater cultural diversity in society. It is documented in the $9^{\text {th }}$ National Economic and Social Development Plan which relate to governance quality before the crisis that-Budget spending in a number of government departments was wasteful, and investment in large development projects was no transparent. The bureaucratic system was not consistent with the economic and social changes, particularly in terms of its obsolete and inflexible regulations, which led to greater use of discretionary judgment by officials. Government officials were not held accountable, while the state enterprise' operations were neither efficient nor transparent, thereby intensifying corruption, a chronic ailment in Thai society. The private sector ran its business imprudently, for example, extending loans to highrisk projects and improper profit taking, resulting in a decline in the local business sector and the whole economy [7]. 


\subsection{Failure in Strengthening Governance through Constitutional Reform}

It is widely believed that constitutional reform can be a vital tool to promote the good governance ${ }^{4}$. It has become a popular method for countries to account for the past institutional failures, to reconstruct the political structures after authoritarian rule, and to ensure better governance for the future. In the last decade alone, Dressel [8] indicates that roughly 70 emerging democracies have completely rewritten or substantially altered their constitutions and Thailand is one of them. He refers to Thailand's 1997 constitutional reform as a particularly interesting case study in trying to address the governance deficiencies through the institutional means while employing a highly innovative process for drafting itself. The new constitution contains several unique features of governance which apart from the predecessors, including: 1) strengthening the rule of law and human rights; 2) enhancing accountability mechanisms and enforcing much stronger conflict of interest standards; 3) improving transparency, participation and decentralization; and 4) changing the electoral and legislative processes.

With the assistance of The World Bank, the Thai Government started her public sector reform in governance since 1999 after the 1997 new constitution. Efforts to function governance had been undertaken extensively, though in a limited way. To demonstrate Thailand's anxiousness in her reform, Damrong Thandee [9] summarized the process by which the government reform governance that - the office of the Public Sector Development Commission was established on October 3, 2003. Six days later the Royal Degree was officially declared on criteria and procedures for good governance in order to further the country's intention to reshape Thailand through the bureaucratic reform and development. Meanwhile, the National Corporate Governance Committee was set up to draw out policies, measures and schemes to upgrade the level of corporate governance in business. The academia, the mass media and the high-ranking officials joined hands to echo the principles of good governance by informing as well as by educating the citizens about the issue. They accordingly outlined the major principles of the rule of law, the morality, the accountability, the participation, the responsibility, and the cost-effectiveness in the public sector.

Half a decade later, some were skeptical on the outcome of the constitutional reform. Several studies that relate the impact of governance on public administration to economic development are not satisfied with the results after reform. It is reported in the Thailand's $9^{\text {th }}$ and $10^{\text {th }}$ National Economic and Social Development Plan (2002-2011) [10] that the past developments have not been able to move the national administration system towards a real good governance system. It provides changes in forms but it could not be driven to implement extensively. The government administration still lacks of good governance because it remains centralized. Although overall administration system and mechanism allow people to participate, it is not enough and not beneficial for creating efficiency, effectiveness and justice in order to be ready for changes. The system denies opportunities for popular participation in decision-making. Moreover, the judicial and legal systems have not adjusted in step with change and are unable to provide justice for all parties. Mechanisms for monitoring the use of state power remain inefficient. The checks-and-balances of private-sector still have a limited role, and lack of ability to build a collective network that could monitor effectively. Though transparency in government administration shows a tendency to improve, and the rating by Transparency International rose to 3.8 out of 10 in 2005, however, it drops to 3.4 in 2009. The deep-seated patronage system remains an obstacle to the spread of good governance in Thailand. Coupled with a lack of quality and public consciousness, it results in an inability to separate individual benefit from public benefit, leading to more complex problems of injustice and corrupt practice.

Another study by Surin Maisrikrod [11] who assesses the relationship among political-administrative accountability, civil society and a new form of governance in Thailand, points out that the new system of governance in Thailand is not being achieved as envisaged by the 1997 constitution, because the pro-market forces and businessmen-politicians are more dominant, resulting in the erosion of accountability and transparency, causing a development of “corporatized governance” instead of participatory governance.

Upon investigating the scores of WGI for Thailand during the period of 1996-2009, The indicators show that after the new constitution came into force in 1997, the aggregate score of governance shows an improvement in the year of 1999 and 2000, where the score increased from 1.662 in 1997 to 1.802 in 2000 . A continual decline in governance quality was noticed from the estimated scores in the year after 2000 (Table 2). Of the six composite indicators, only two of them: "Regulatory Quality" and "Government Effectiveness" remain their positive sign over the period of study. The declining in most of the governance scores overtime after the year of 2000 reflects the failure of new institutions and of other provisions which targeted at good governance through constitution.

The constitutional reform, however, do not totally fail. At least in the study of Pasuk Phongpaichit [12] (2001) on the bureaucratic and political corruption, she agrees that the new constitution contains many innovations which aim to make it costlier and riskier for the politicians and

${ }^{4}$ Constitutional reform is the process of reconstructing the constitution and the laws that govern through public consultation and negotiation. 
Table 2. The scores of governance indicators.

\begin{tabular}{cccccccc}
\hline & VA & PV & GE & RQ & RL & CC & Aggregate Scores \\
\cline { 2 - 7 } 1996 & 0.292 & 0.133 & 0.432 & 0.455 & 0.626 & -0.276 & 1.662 \\
1997 & 0.344 & 0.305 & 0.26 & 0.308 & 0.566 & -0.122 & 1.661 \\
1998 & 0.397 & 0.477 & 0.088 & 0.162 & 0.506 & 0.031 & 1.660 \\
1999 & 0.454 & 0.454 & 0.079 & 0.31 & 0.511 & -0.077 & 1.731 \\
2000 & 0.51 & 0.431 & 0.071 & 0.459 & 0.516 & -0.184 & 1.802 \\
2001 & 0.425 & 0.463 & 0.145 & 0.321 & 0.411 & -0.239 & 1.526 \\
2002 & 0.339 & 0.495 & 0.219 & 0.183 & 0.307 & -0.293 & 1.251 \\
2003 & 0.258 & -0.367 & 0.346 & 0.282 & 0.106 & -0.177 & 0.448 \\
2004 & 0.125 & -0.367 & 0.287 & 0.282 & 0.072 & -0.171 & 0.227 \\
2005 & 0.031 & -0.544 & 0.454 & 0.458 & 0.142 & -0.009 & 0.531 \\
2006 & -0.551 & -0.922 & 0.356 & 0.287 & 0.038 & -0.21 & -1.002 \\
2007 & -0.612 & -0.996 & 0.349 & 0.164 & -0.019 & -0.288 & -1.402 \\
2008 & -0.513 & -1.092 & 0.188 & 0.286 & -0.065 & -0.386 & -1.583 \\
2009 & -0.403 & -1.105 & 0.152 & 0.367 & -0.134 & -0.232 & -1.355 \\
\hline
\end{tabular}

the bureaucrats to abuse their position for personal gain. But the impact on the quality of governance is still minimal because law enforcement remains weak and civil society is not active in their participatory roles, which slow down the reform process. She believed that participation of the people is critical to the success of efforts to put in place the new independent institutions to ensure the human rights, the community rights, and the rights of citizens to investigate the behavior of the politicians and the bureaucrats.

Similarly, Domrong Thandee [13] admits that the outcome has turned out in mixed results. On the one hand, several public organizations and personnel were awarded for their outstanding achievement in the field of performance and philanthropy in several occasions. On the other hand, corruption and nepotism still prevailed, the Transparency International places Thailand at 84th in corruption perceptions index in 2009. That is to say that Thailand slips back from 11th place to 14th in the AsiaPacific index and from 63rd to 84th in the overall 180nation world index.

\section{Results of the Study}

Results of the study are divided into 3 parts. The first part is an analysis of the relationship among the six governance composite indicators for Thailand. The second part presents correlation between growth and poverty indicators. In the third part, the linkage between governance indictors and poverty indicators will be explored and analyzed.

\subsection{Correlation among Governance Composite Indicators for Thailand}

Of the six governance composite indicators for Thailand, correlation coefficients show that there are three dimen-
Table 3. Pearson correlation coefficients of the six World Governance Indicators (WGI).

\begin{tabular}{ccccccc}
\hline & VA & PV & GE & RQ & RL & CC \\
\cline { 2 - 7 } VA & 1 & & & & & \\
PV & $0.941^{* * *}$ & 1 & & & & \\
GE & -0.341 & -0.421 & 1 & & & \\
RQ & 0.199 & $0.026^{*}$ & 0.188 & 1 & & \\
RL & $0.840^{* * *}$ & $0.909^{* * *}$ & -0.258 & 0.214 & 1 & \\
CC & $0.459^{*}$ & 0.378 & -0.101 & 0.075 & 0.374 & 1 \\
\hline
\end{tabular}

${ }^{* * * *}$ represents the 0.01 level of significant (2- tailed), ${ }^{* *}$-the 0.05 level, and * - the 0.10 level.

sions that have high positive correlation with coefficients value between 0.8 and 0.9 . Indicators that represent these three dimensions are Voice and Accountability, Political Stability and Absence of Violence, and Rule of Law (Table 3).

High correlation among the three dimensions of governance indicator lies on the facts that they are correlated and reinforcing each other in Thailand. That is-when overall administration system and mechanism do not fully allow opportunities for popular participation in decision-making, the judicial and legal systems do not have enough adjusted in step with change and are unable to provide justice for all parties, and the weak results in these two governance indicators lead to political instability afterward.

It is evident that the scores which measure perception on the three governance indicators have been declining after one year of the Thai Rak Thai Party's won election in the 2001 (Table 2). Maisrikrod [14] points out that Thai people are disappointed in the new constitution of 1997 which aimed to establish a stronger participatory democracy and hence strong accountability and transparency in government, but the charter seems to have 
failed to produce the desired outcome because capitalists and corporate elites have captured the electoral process which is the means by which state power is achieved. In addition, it is also apparent that the government also put pressure on Constitutional Court which rules out Thai people's reliability on judicial and legal systems. Since 2003, there appears a declining in scores of "Political Stability and Absence of Violence" indicator, which reflects the increasing likelihood that the government will be destabilized or overthrown by unconstitutional or violent means, including politically-motivated violence and terrorism. The weak political stability during 2003-2004 is due to the belief that the Thai Rak Thai Party with its electoral dominance ignore claims from civil society that the government is undermining accountability and transparency, and in fact condoning actions that go against the principles of good governance.

The perception score on political stability however has been even worsening when Bangkok has been rocked by political turmoil since 2005, and particularly since a military coup deposed popularly-elected Prime Minister Thaksin Shinawatra in September 2006. An interim military government struggled to rule until it staged elections in December 2007. Although the Thai Rak Thai Party's successor won the most seats, two successive prime ministers were forced to resign because of controversial rulings by Thailand's high court. Both decisions raised concerns that Thailand's judicial system was being used for political purposes. Even though lawmakers realigned into a new ruling coalition and Abhisit Vejjajiva of the Democrat Party assumed the premier post, protesters have continued to disrupt the country since then [15].

\subsection{Is Growth Essential to Reduce Poverty in Thailand?}

Several countries, particularly in Asia, have seen soaring economic growth as well as poverty reduction over the last decade. But when it comes to income inequality improvement, they have made more limited progress. A study of Eastwood, et al. [16], using data during the mid 1980s and the late 1990s demonstrates that the relationship between growth and poverty reduction varies among countries. Some countries whose per-capita growth rates are similar like Ghana and Brazil; the poor fared better in Ghana where incomes of the poor grow by 1.6 percent per year, higher than in Brazil which grew by only 0.6 percent per year.

For Thailand, throughout the period of study, Thailand has achieved both high rates of economic growth and a rapid decline in the incidence of poverty. But the growth does not benefit all equally since Gini coefficients remain quite stable (Table 1). By using Pearson's correlation during the period of 1996-2009, it is shown in Table 4 that there are no correlations among the economic growths, the income inequality and the poverty level. The results are consistent with the study of Krongkaew, et al. [17] who study the linkages among the incidence of poverty, the economic growth and the employment by means of multiple regression. The study shows that GDP growth rate is not statistically significant in reducing poverty as measured by headcount ratios. The result suggests that the poverty reduction and a slightly improvement in income distribution of Thailand might not due to the economic growth but is affected through governance malpractice.

Table 4. Pearson correlation coefficients between growth and poverty.

\begin{tabular}{|c|c|c|c|c|c|c|c|c|}
\hline & $\begin{array}{l}\text { GDP growth at } \\
1988 \text { price }\end{array}$ & $\begin{array}{l}\text { GDP per capita } \\
\text { growth (\%) }\end{array}$ & $\begin{array}{l}\text { Per capita } \\
\text { GDP (baht) }\end{array}$ & $\begin{array}{l}\text { Proportion } \\
\text { below the } \\
\text { poverty line }\end{array}$ & $\begin{array}{l}\text { Poverty gap } \\
\text { ratio }\end{array}$ & $\begin{array}{c}\text { Share of poorest } \\
\text { quintile in individual } \\
\text { household expenditure }\end{array}$ & $\begin{array}{l}\text { Proportion } \\
\text { below food } \\
\text { poverty line }\end{array}$ & $\begin{array}{l}\text { Gini } \\
\text { coefficient }\end{array}$ \\
\hline $\begin{array}{l}\text { GDP growth at } 1988 \\
\text { price }\end{array}$ & 1 & & & & & & & \\
\hline $\begin{array}{l}\text { GDP per capita } \\
\text { growth (\%) }\end{array}$ & $0.989^{* * *}$ & 1 & & & & & & \\
\hline Per capita GDP (baht) & $0.989^{* * *}$ & 0.333 & 1 & & & & & \\
\hline $\begin{array}{l}\text { Proportion below the } \\
\text { poverty line }\end{array}$ & -0.159 & -0.232 & $-0.948^{* * *}$ & 1 & & & & \\
\hline Poverty gap ratio & -0.295 & -0.304 & $-0.929^{* * *}$ & $0.998^{* * *}$ & 1 & & & \\
\hline $\begin{array}{c}\text { Share of poorest } \\
\text { quintile in individual } \\
\text { household expenditure }\end{array}$ & -0.509 & -0.503 & 0.179 & -0.172 & -0.214 & 1 & & \\
\hline $\begin{array}{l}\text { Proportion below food } \\
\text { poverty line }\end{array}$ & -0.373 & -0.377 & $-0.779^{* * *}$ & $0.904^{* * *}$ & $0.922^{* * *}$ & -0.099 & 1 & \\
\hline Gini coefficient & 0.471 & 0.379 & $-0.618 * *$ & $0.597 * *$ & 0.54 & $-0.865^{* * *}$ & 0.424 & 1 \\
\hline
\end{tabular}

Note: ${ }^{* * *}$ represents the 0.01 level of significant (2-tailed), ${ }^{* *}$ — the 0.05 level, and ${ }^{*}$ - the 0.10 level. 
In addition, there are also other studies on poverty and economic growth such as Kakwani [18] and Francois Bourguignon [19] who agree that economic growth alone is insufficient for enhancing poverty reduction equally. They believe that the type of growth that has a beneficial effect on both poverty reduction and improved income distribution is "pro-poor" growth, which is often defined as the growth which improves the income position of the poor relatively more than that of the non-poor.

To measure a beneficial effect of which the growth has on both poverty reduction and income distribution, Nanak Kakwani, et al. [20], for example, proposed a new indicator "the pro-poor growth index". In their study for three countries, namely, Lao PDR, Thailand and Korea; the result for Thailand indicates that growth has not been strictly pro-poor, although it has yielded considerable poverty reduction in some period. A more detailed study in this context is by Krongkaew, et al. [21] who elaborate further that economic growth in Thailand reduced the poverty faster than it would have been only in some certain periods like 1992-1994, 1994-1996, and 2000-2002. The result explains why the growth, the proportion of the poor below the poverty line, and the Gini coefficient do not statistically significant correlated.

Nanak Kakwani, et al. [22] urge that the relation among growth, inequality and poverty is complex and interdependent one. For a poverty reduction policy to be effecttive, it is necessary to include an agenda that addresses both distributional concerns and poverty reduction, for they could lead to the enhancement of both economic growth and equity. It is suggested by Blaxall [23] that mere policy agenda per se may not be enough for poverty reduction efforts to be effective. The power to exercise such policy in a proper way is an essential component of any strategy for reducing poverty. Without good governance practice, power to be exercised through a country's economic, social, and political institutions would be abused, or exercised in weak or improper ways, those with least power-the poor-would be those most likely to suffer. Weak governance compromises the delivery of services and benefits to those who need them most; the influence of powerful interest groups biases policies, programs and spending away from the poor; and lack of property rights, police protection and legal services disadvantages the poor and inhibits them from securing their homes and other assets and operating businesses. Thus poor governance generates and reinforces poverty and also subverts efforts to reduce it. Strengthening governance is an essential precondition to improving the lives of the poor.

This paper intend to support the line of thought that the improvement in poverty incidence and a persistence of high level in income inequality in Thailand do not originates from the lack of resources but from the failures of governance practice.

\subsection{Governance and Poverty Reduction Linkage}

There is lots of evidence from countries around the world supporting that good governance reduces poverty, and that bad governance leads to poverty. In economic theory, there are at least three ways of connecting the governance and the poverty reduction: 1) economic growth; 2) effectiveness of aid; and 3) human development (Martin, 2004). It is generally believed that the economic growth is one of the crucial factors for poverty reduction, and the quality of governance correlate to and the economic performance in terms of growth has proliferated, because the good governance spurs the economic growth that would consequently reduces the poverty. A study of Kaufmann et al. [24] for example found that per capita incomes and the quality of governance are strongly positively correlated across countries.

It is advocated in this study that the good governance would spurs economic growth and would consequently reduce poverty only when the type of growth is pro-poor. The good governance is essential for pro-poor growth policy to be effective. If the administrative power in exercising policy is in line with good governance, institutions would function transparently and would be accountable and accessible to the public, poor people would have access to basic services, they would have opportunities to pursue their livelihoods. Sumarto [25] elaborates further that without good governance, availability of the scarce resources are generally not put to their best use in combating poverty and would hinder economic growth that could help pull the poor out of poverty.

Good governance in public spending, for example, can help reduce poverty implicitly, by improving services and reducing waste, but public spending may not be explicitly oriented to the poor. To increase its pro-poor impact, it may help to concentrate public spending in areas that are relatively more important to the poor, such as preventive health care services or primary education or rural roads, water supply and sanitation. Governments can also use transfer programs that identify the poor based on their income or household characteristics and attempt to channel income or in-kind payments to them.

It is mentioned earlier that the correlation between the economic growth and the poverty indicators are not statistically significant because the type of growth in Thailand has not been strictly pro-poor. In this part, the Pearson Correlation Coefficients in Table 5 show that poverty level and the Gini coefficient are highly correlated to the aggregate score of World Governance Indicator (WGI). The positive correlation between the poverty level and the WGI score indicates that the poor becomes poorer 
when the quality of governance is low in Thailand of which the data of aggregate WGI score are continually decline since 2001.

In addition, it is also found that the per capita GDP at constant 1988 price shows high negative correlation to the governance indicator. The result suggests that bad governance in Thailand does not only adversely affect income of the poor, but also the average income of all sectors. The result conforms to the general view that poor governance tend to reinforce poverty in the society.

The positive correlation between the Gini inequality index and the aggregate WGI indicator, on the other hand, implies a better income distribution in light of declining governance quality. This reflects the facts that perception on governance quality in general is negative when Thai government has been utilized populist policies by spending a large amount of money in the budget to help the poor since 2000.

Among the six composite indicators, there are only three of them: Voice and Accountability, Political Stability and Absence of Violence, and Rule of Law that are

Table 5. Pearson correlation between the aggregate score of WGI, growth and poverty indicators.

\begin{tabular}{|c|c|c|c|c|c|c|}
\hline & $\begin{array}{l}\text { Proportion } \\
\text { below the } \\
\text { poverty line }\end{array}$ & $\begin{array}{c}\text { Per capita } \\
\text { GDP (baht) }\end{array}$ & $\begin{array}{l}\text { Per capita } \\
\text { GDP } \\
\text { growth (\%) }\end{array}$ & $\begin{array}{c}\text { GDP } \\
\text { growth at } \\
1988 \text { price }\end{array}$ & $\begin{array}{c}\text { Gini } \\
\text { coefficient }\end{array}$ & WGI \\
\hline $\begin{array}{l}\text { Proportion } \\
\text { below the } \\
\text { poverty line }\end{array}$ & 1 & & & & & \\
\hline $\begin{array}{l}\text { Per capita } \\
\text { GDP (baht) }\end{array}$ & $-0.948^{* * *}$ & 1 & & & & \\
\hline $\begin{array}{l}\text { Per capita } \\
\text { GDP growth } \\
\text { (\%) }\end{array}$ & -0.232 & 0.333 & 1 & & & \\
\hline $\begin{array}{l}\text { GDP growth } \\
\text { at } 1988 \text { price }\end{array}$ & -0.159 & 0.248 & $0.989^{* *}$ & 1 & & \\
\hline $\begin{array}{c}\text { Gini } \\
\text { coefficient }\end{array}$ & $0.597^{*}$ & $-0.618^{*}$ & 0.379 & 0.471 & 1 & \\
\hline WGI & $0.909^{* *}$ & $-0.955^{* *}$ & -0.201 & -0.12 & $0.697^{* *}$ & 1 \\
\hline
\end{tabular}

**** represents the 0.01 level of significant (2-tailed), ${ }^{* *}$ - the 0.05 level, and * - the 0.10 level.

Table 6. Pearson correlation coefficients between composite governance indicators, growth and poverty indicators.

\begin{tabular}{ccccc}
\hline $\begin{array}{c}\text { WGI } \\
\text { indicators }\end{array}$ & Poverty level & $\begin{array}{c}\text { Per capita } \\
\text { GDP (baht) }\end{array}$ & $\begin{array}{c}\text { Gini } \\
\text { coefficient }\end{array}$ & $\begin{array}{c}\text { Per capita GDP } \\
\text { growth (\%) }\end{array}$ \\
\hline VA & $0.896^{* * *}$ & $-0.932^{* * *}$ & $0.628^{* *}$ & -0.159 \\
PV & $0.937^{* * *}$ & $-0.971^{* * *}$ & $0.605^{* *}$ & -0.256 \\
GE & $-0.562^{* *}$ & 0.434 & 0.191 & $0.479^{*}$ \\
RQ & 0.146 & -0.013 & 0.316 & 0.324 \\
RL & $0.889^{* * *}$ & $-0.911^{* * *}$ & $0.644^{* *}$ & -0.275 \\
CC & 0.366 & $-0.494^{*}$ & 0.342 & $-0.476^{*}$ \\
\hline
\end{tabular}

${ }^{* * *}$ represents the 0.01 level of significant (2-tailed), ${ }^{* *}$ - the 0.05 level, and * - the 0.10 level. highly correlated to one another (Table 3). This study will focus on the relationship among these three composite indicators, the poverty level and the income inequality. It is found that the three dimensions show high correlation coefficients of $0.8-0.9$ to the poverty indicators (proportion of population below the poverty line, and the Gini coefficient), but the linkage between growth and poverty indicators are not statistically significant. The results confirm that economic growth is not the main factor in eradicating poverty in Thailand as normally cited; instead, it is the quality of governance that affects poverty reduction. The positive correlation between each of the three governance dimensions and poverty indicators reveals the facts that eradication of poverty in Thailand is success through political channel not by economic means. The Thai government during the period of study spent money to buy votes both directly and indirectly. Disappointment in populist policies and conflicts among laws, directives, rules and regulations lead to political stability afterward.

The only indicator that reflects positive perception of the quality of public services and the civil service, etc., and shows moderately importance in reducing the number of the poor in line with the accepted principle is Government Effectiveness. In this dimension, even though the WGI score has been declining since 2006, it still reflects the positive perception of the quality of public services and the civil service, etc. Table 5 shows that it is the only dimension that indicates moderately importance in reducing the number of the poor in line with the accepted principle.

The Regulatory Quality indicator displays positive perception of the ability of the government to formulate and to implement sound policies and regulations that permit and promote private sector development over the studied period. This owes to the facts that Thailand has achieved some of the most significant growth in the private sector which participates in infrastructure, which leads to the moderate growth in GDP, but its correlation with poverty indicators is not statistically significant.

Control of Corruption remains the only indicator that Thai people have negative perception of the extent to which public power is exercised throughout the period of study (Table 2), indicating that even though the overall performance of the government sector has improved, but the capacity for addressing corruption is still weak. Table 6 shows that the lack of good governance in this dimension does have negative impact on the per capita GDP at constant price as well as the GDP per capital growth. But it does not have any correlation to any poverty indicators. This implies that corruption incidence in Thailand affect the income of Thai people equally not only the poor.

Unfortunately, number of 14 observations in this study 
is not sufficient to conduct causality test to detect the cause and effect of relationship among the three indicators.

\section{Conclusions and Policy Implications}

Throughout the period of study, Thailand had achieved both high rates of economic growth and a rapid decline in the poverty level, but the overall income disparity as measured by Gini coefficient remains quite stable. Results of this study show that the poverty reduction in Thailand is achieved through populist policies which are exercised with low quality of governance, not through growth. It supports general belief that the "pro-poor growth" policy alone without good governance performance is insufficient for enhancing poverty reduction equally.

Results of this study tend to support general belief that the "pro-poor growth" policy alone is insufficient for enhancing poverty reduction equally. It is advocated in this study that the good governance is essential for pro-poor growth policy to be effective and to reinforce the process of being more equitable in income distribution.

For Thailand to sustain its growth and to avoid the persistence of high income inequality, the country needs to reform at least three dimensions of governance quality, namely Voice and Accountability, Political Stability and Absence of Violence, and Rule of Law. Politicians should stop throwing money around in the name of poverty reduction program in order to garner votes. Empowering the poor by allowing them to participate in formal political and administrative processes as generally belief may not be sufficient to guarantee legitimate transfer of power to the poor. For a developing country like Thailand, the emphasis on empowering the poor first with better education and training to increase their productivity and hence income is more vital. With regard to the maintenance of public order, the laws should be enforced on a fair and non-discriminatory basis that can let them be free from politician intervention. Political stability would follow if the perception on the two aspects; Voice and Accountability and Rule of Law are acceptable by the Thai.

\section{REFERENCES}

[1] N. Girishankar, L. Hammergren, M. Holmes, et al., "Governance and Poverty Reduction," Draft for Comments within the World Bank and from Comments Provided at PRSP Workshops, April 2001, p. 2.

[2] M. G. Martin, "Governance and Poverty Reduction: Paths of Connection," Trocaire Development Review, Dubin, 2006, p. 35.

[3] D. Kaufmann, A. Kraay and M. Mastruzzi, “The Worldwide Governance Indicators, Methodology and Analytical Issues,” Policy Research Working Paper 5430 for the World Bank Development Research Group, Macroeconomics and Growth Team, September 2010.

[4] M. Krongkaew, S. Chamnivickorn and I. Nitithanprapas,
“Economic Growth, Employment, and Poverty Reduction linkages: The Case of Thailand," Issues in Employment and Poverty Discussion Paper 20, January 2006, pp. 2730.

[5] E. Chanlett-Avery, "Political Turmoil in Thailand and US Interests,” CRS Report for Congress, Prepared for Members and Committees of Congress, 26 May 2009, pp. 1-5.

[6] Asian Development Bank, “ADB Annual Report,” ISSN 306-8370 (print), April 2000.

[7] National Economic and Social Development Board, “Good Governance Strategies," Thailand's 9th National Economic and Social Development Plan 2002-2006, Chapter 2, 2002.

[8] B. Dressel, "Strengthening Governance through Constitutional Reform, The Governance Brief (ADB)," A Quarterly Publication Capacity Development and Governance Division Regional and Sustainable Development Department, No. 13, 2005.

[9] D. Thandee, "Good Governance in Thailand: Limitations and Challenges," Proceedings of the Seminar on Good Governance, Economy, Education, Culture and Tourism of Thailand and Korea, The Institute of East Asian Studies of Thammasat University, Khlong Nueng, 10-11 February 2010, pp. 14-18.

[10] National Economic and Social Development Board, "Thailand's 9th National Economic and Social Development Plan 2002-2006," Chapter 2, and “Thailand's 10th National Economic and Social Development Plan 20072011," Chapters 1 and 6.

[11] S. Maisrikrod, "Civil Society, Accountability and Governance in Thailand: A Dim Case of Participatory Democracy," Institute of Southeast Asian Studies, Institute of Southeast Asian Studies, 2008, pp. 97-98.

[12] P. Phongpaichit, “Good Governance: Thailand's Experience,” Paper for Asia Pacific Finance Association (APFA) Annual Conference, July 2001.

[13] D. Thandee, "Good Governance in Thailand: Limitations and Challenges,” op.cit., pp. 15-16.

[14] S. Maisrikrod, "Civil Society, Accountability and Governance in Thailand: A Dim Case of Participatory Democracy,” op.cit., pp. 97-114.

[15] E. Chanlett-Avery, "Political Turmoil in Thailand and US Interests,” op. cit., p. 1.

[16] R. Eastwood and M. Lipton, "Pro-Poor Growth and ProGrowth Poverty Reduction: Meaning, Evidence and Policy Implications,” Asian Development Review, Vol. 18, No. 2, 2001, pp. 22-58.

[17] M. Krongkaew, S. Chamnivickorn and I. Nitithanprapas, "Economic growth, Employment, and Poverty Reduction Linkages: The Case of Thailand,” op. cit., pp. 27-30

[18] N. Kakwani and E. Pernia, "What Is Pro-Poor Growth?” Asian Development Review, Vol. 18, No. 1, 2000, pp. 116.

[19] B. Francois, "The Growth Elasticity of Poverty Reduction: Explaining Heterogeneity across Countries and Time Periods,” DELTA Working Papers, Paris, 2002-2003.

[20] N. Kakwani and E. Pernia, "What Is Pro-Poor Growth?" 
op. cit., pp. 1-14.

[21] M. Krongkaew, S. Chamnivickorn and I. Nitithanprapas, "Economic Growth, Employment, and Poverty Reduction Linkages: The Case of Thailand,” op. cit., pp. 44-45.

[22] N. Kakwani and E. Pernia, "What Is Pro-poor Growth?” op. cit., pp. 1-14.

[23] J. Blaxall, “Governance and Poverty,” Joint Workshop on Poverty Reduction Strategies in Mongolia, Ulaanbaatar, 4-6 October 2000, pp. 1-4.
[24] D. Kaufmann, A. Kraay and M. Mastruzzi, "Governance Matters IV: New Data, New Challenges,” World Bank, Washington DC, 2005.

www.worldbank.org/wbi/governance/pubs/govmatters4.h tml

[25] S. Sumarto, A. Suryahadi and A. Arifianto, "Governance and Poverty Reduction: Evidence from Newly Decentralized Indonesia,” Working Paper, SMERU Research Institute, March 2004. 